\title{
Marxist psychology: a research paradigm whose time has come
}

\author{
Psicologia marxista: um paradigma \\ de pesquisa cuja hora chegou
}

\author{
Mohamed ELHAMMOUMI ${ }^{1}$
}

\begin{abstract}
This paper seeks to retrieve Marx's ideas about the development of psychology. It offers historical perspectives on different attempts to create a Marxist psychology that shed light on its scope and trajectory. According to Marx, concrete social and material real life play a key role in the development of human psychological functions. Later, Vygotsky, Wallon, Politzer, Leontiev, Luria, Sève among others built on Marx's ideas. These psychologists suggested that individual psychological functions are formed and shaped in concrete, cultural, social, historical circumstances, and pictured an organizing, creative force driving individual activity (instead of behavior). Marxist psychology is the study of the social individual within social relations of production. In a Marxist sense, the emphasis is placed on production, both material and social as the essence of social relations. Hence, psychology cannot be dealt with in an abstract, private and individual manner as the capitalist mode of production would want, but must be seen in terms of the social individual that is formed, structured, and shaped within the social relations of a production framework. In this context, the social production of the individual (as developed in Marx's Die Grundrisse) signifies social relations between people connected with concrete common real social conditions and material production. Production, both social and material, is the totality of social relations. In the process of production, social individuals act not only upon nature but also upon one another, they enter into a definite rich web of connections and relations to one another. Marx's writings encompassed the fields of psychology and made a substantial contribution to the stock of knowledge about human nature processes. Marx never wrote a full-length treatise on psychology, though his own work is the outstanding example of psychological conceptualizations. This paper stresses the decisive relevance of Marx's psychological conceptions for a paradigm shift whose time has come.
\end{abstract}

Uniterms: Communism. Marxist psychology. Social interaction.

\section{Resumo}

Este artigo busca recuperar as ideias de Marx sobre o desenvolvimento da Psicologia. Apresenta abordagens históricas sobre as diversas tentativas de criar uma psicologia marxista que elucidam sobre a sua abrangência e trajetória. Segundo Marx, a vida real material e a vida social concreta desempenham um papel-chave no desenvolvimento das funções psicológicas humanas. Mais tarde, Vygotsky, Wallon, Politzer, Leontiev, Luria, Sève, entre outros, elaboraram seus trabalhos a partir das ideias do Marx. Estes estudiosos sugeriram que as funções psicológicas das pessoas são formadas e moldadas em circunstâncias concretas, culturais, sociais e históricas, e imaginaram uma força organizadora e criativa conduzindo atividade individual (em vez de comportamento). A psicologia marxista éo estudo do indivíduo social dentro das relações sociais de produção. Em um sentido marxista, a ênfaseéna produção, tanto material quanto social, como a essência das relações sociais. Portanto, não se pode tratar a Psicologia de forma abstrata, privada e individual como o modo capitalista de produção gostaria, mas ela deverá ser considerada em relação ao indivíduo social que éformado, estruturado e moldado dentro das relações sociais

\footnotetext{
$\boldsymbol{\nabla \nabla \nabla \nabla}$
}

1 Al-Imam Muhammad Ibn Saud Islamic University, College of Social Sciences, Department of Psychology. 13318, Riyadh, Saudi Arabia. E-mail: $<$ Elhammoumim@hotmail.com>. 
de uma estrutura de produção. Neste contexto, a produção social do indivíduo (como elaborada em Die Grundrisse do Marx) significa as relações sociais entre pessoas conectadas às condições sociais reais e comuns e a produção material. A produção, tanto social como material, é a totalidade das relações sociais. No processo de produção, os indivíduos sociais agem não apenas a partir da natureza, mas também a partir dos outros indivíduos, entrando numa rede definitiva erica de conexões e relações entre si. As obras do Marx abrangeram os campos de Psicologia e contribuíram de forma substancial ao conhecimento sobre os processes da natureza humana. Marx nunca escreveu um tratado completo sobre a Psicologia, embora seu próprio trabalho seja o exemplo mais importante de conceptualizações psicológicas. Este artigo sublinh a a relevância decisiva das concepções psicológicas de Marxem relação a uma mudança paradigmática, cuja hora já chegou.

Unitermos: Comunismo. Interação social. Psicologia marxista

Marxist psychology is... the only genuine psychology as a science... A psychology other than this [Marxist psychology] cannot exist... everything that was and is genuinely scientific belongs to Marxist psychology. This concept... coincides with the concept scientific per se (Vygotsky, 1997).

If, in the history of Marxist psychology, the period from 1917 to the late 1920s can be characterized as a period of Leninism, from the early 1930s to early 1950s as that of Stalinism, from the late 1950s to the early 1970s as that of Maoism, and from the mid-1970s to the early 1980s as that of Gramscism, then the early 1980s to the early 1990s can be referred to as the age of global liberal capitalism. The Russian and Chinese models of communism have exhausted their versions of Marxism and have found accommodation within a world order liberal capitalism. Every generation of Marxists since Marx's death has managed to come up with a new version of understanding Marxism in an attempt to comprehend, interpret and deal with complex concrete reality, social conditions and the dynamic totality of social life. Thus, any reading of Marx's writings or Marxist psychologists' contribution to Psychology must be situated within the historical movement of Marxism.

In this paper I have attempted to defend the idea that the academic discipline of Marxist psychology (scientific psychology as Vygotsky termed it) had a short history but produced a wealth of insights Holzkamp (1992), Leontiev (1978;1981), Luria (1966), Parker (2007), Politzer (1929/1969a; 1929/1969b), Sève (1966; 1975; 1978; 1989; 2002; 2008), Tobach (1999), Wallon(1951), Vygotsky (1994a; 1928/1993; 1933/1987; 1981; 1989; 1994b, 1997). These insights have been largely ignored by contemporary, empirically-minded psychologists and educators as well as researchers and investigators in the field of psychological sciences. The aim of this paper is to reconstruct at least part of this heritage and shed light on the unfinished project of a Marxist psychology; a project that has been subjected to neglect, misunderstanding, and misuse. The heritage as well as the legacy of Marxist ideas to Psychology will be investigated. What is a Marxist psychology? Defining it is hard enough, giving it to a psychologist is even harder. The answer to this question can be found in Marxism itself. Vygotsky (1927/1997, p.341) pointed out that,

Marxist psychology is... the only genuine psychology as a science.... A psychology other than this [Marxist psychology] cannot exist... everything that was and is genuinely scientific belongs to Marxist psychology. This concept... coincides with the concept scientific perse.

Far from being exhausted, Marx's idea of psychology is still very young, almost in its infancy; it has scarcely begun to develop (Sartre, 1960, p.30).

Psychology can play a major role in (re)-building a society that can foster immense human potentialities through education and learning processes. In this regards, Marx (1844/1963, p.52) argued that, "To be radical is to grasp things by the root. But for man the root is man himself". Marx, emphasized the active role of human individuals in creating their own world, rather than merely existing as a result of the environment. The empirically-minded, mainstream psychologists regarded data of experience as objective reality, thus leaving to the perceiving individual the task of passive recognition. But Marx, on the contrary, argued that processes of perception and processes of thought were both in the concrete realm of human praxis or subjective activity. 
Marx pointed out that there is an active interaction between human individuals and society. The human individual is thoroughly social, connected with society, and in constant development through the powerful demands of society. In this paper I will also explore the dialectical relationships between the rule-governed human behavior and the shaping of human higher mental functions by socializing experiences and socially organized practical activity. Psychologists have interpreted human nature, behavior and higher mental functions in various ways but the goal of psychology is to change human nature. This later thesis can be expanded one step further by stating that if we want to change human nature we must change social relations. In my view, Marxist psychology would be more satisfactory at the first stage in understanding human nature rather than changing it.

\section{Marxist psychology}

The way in which the academic study of Vygotsky and his disciples has evolved over the last three decades has been heavily influenced, as have most areas of psychological theories, by broader shifts in intellectual paradigms (positivism, behaviorism, cognitivism, structuralism, humanism, modernism, constructionism, postmodernism, critical realism, postpositivism, etc.). Thus, a useful way of looking at the history of interpretation of Marxist psychology through research in the West (Au, 2007; Bickley, 1977; Clot, 1977; Elhammoumi, 2001a, 2001b, 2002a, 2002b, 2002c, 2006, 2009, 2010; Eskola, 1992; Holzkamp, 1992; Le Ny, 1970; Marlieu, 1983; Mather, 2003; Naville, 1948; Newman \& Holzman, 1993; Packer, 2008; Parker, 2007; Petrovsky, 1990; Quiniou, 1983; Reich 1929/1966, 1934/1972; Roth \& Lee, 2007; Sawchuk, Duarte \& Elhammoumi, 2006; Shah-Shuja, 2008; Shames, 1984; Spears \& Parker, 1996; Veresov, 1999; Vergnaud, 2000) may shed light on this topic.

After all, Vygotsky himself developed his ideas in the shadow of the great enthusiasm of Marxism for positivism and science of the nineteenth century. This scientific outlook fuelled and continued to dominate the theoretical output of all fields of human and social sciences, including psychology. The rise of Stalinism and its consequences in the 1930s shifted the center of Marxist theory from Moscow to Paris and saw the advent of existentialism as the dominant intellectual mode of philosophizing, to be succeeded by the rapid rise and fall of phenomenology, hermeneutics, and humanism in the 1950s, and French vogue for structuralism in the 1960s. The 1970s witnessed the advent of the systematic anarchy of postmodernism; the 1980s saw the so-called oxymoronic rational choice Marxism; the 1990s saw the advent of systematic anarchy of third way liberalism, and in 2000, the apparently oxymoronic global liberal capitalism. The 1990s also witnessed the birth of 'new Hegelian Marxism' that makes a direct parallel between Hegel's logic and Marx's Capital (Max, 1976). In order to understand the theoretical structure of Capital, Arthur (2002), Uno (1980), and Sekine (1997) called for a logical Hegelian interpretation - of Capital. Althusser and his disciples in Reading 'Capital' had already offered one interpretation of Das Kapital as complex theoretical structure (Althusser, 1970a, 1970b; Balibar, 1974; Bidet, 2000). It seems to me that the revival of Vygotsky's ideas must be seen in the context of the competing schools and ideas of Marxism. Psychologists working within Vygotsky's theoretical framework will find in the present debates within Marx's theory a fertile terrain to anchor their ideas and understanding of a cultural-historical psychology project²

The 1980s in the Soviet Union was a time of Perestroika and Glasnost, while Eastern Europe was dominated by Solidarnosch and an embracement of global capitalism and free market economics, culminating in the upheavals of 1990 and the fall of the Soviet Union and Eastern Europe. In the turbulent years of the Perestroika, the six volumes of the collected works of Lev Vygotsky appeared in the Russian language for the first time. There was nothing to rival the Freudo-Marxist psychology and Althusserian structuralism in the terrain of Marxist psychology. In the West, those Marxists

$\boldsymbol{\nabla \nabla \nabla \nabla}$

2 The cultural historical activity theory (CHAT) requires that each category of human higher forms of mental life be analyzed: (a) from an historical perspective; (b) in relation to other complex components of social relations; (c) by taking into account the concrete experience of history. Chaiklin (2001, p.21) defines cultural historical psychology as "the study of the development of psychological functions through social participation in societally-organized practices". 
interested in psychology have tended either to turn towards bourgeois materialism such as Pavlov, behaviorism, psychoanalysis or to concentrate on demonstrating the narrow scope and limitations of Western bourgeois psychology. Soviet and Western Marxist psychology owed more to bourgeois materialism than Marxism. Marx (1844/1963, p.143) in the Paris Manuscripts argued that, "any attempt to create any psychology that ignored the historical development of industry (Marx used the term industry as meaning purposeful human labor, emphasis added) "cannot become a genuine, comprehensive and real science". Therefore, for Marx and Marxist psychologists, psychology is an expression of the division of labor and human alienation. The logical consequence of overcoming the division of labor and alienation is the emergence of a unified psychological science that would be part of a truly human, free labor and enlightened consciousness that would unite the human individual with his/her true human nature. Thus, psychology needs a historical-materialist framework of conception in order to develop as a science. Psychology needs a dialectical materialist method of analysis for the study of human higher mental functions and consciousness. With this method Marx and Engels (1963) discovered the laws and nature of social production and social relations in the process of the historical evolution of human society from tribal, slave, feudal, to capitalist societies. They discovered the separation of society into classes, division of labor, social production of the individual, social relations of production, consciousness, alienation, etc. I was interested in Marx because of his attempt to anchor human ideas in social reality and socially organized practical activity. Human individuals actively create their environment, which in turn gives rise to new forms of higher mental functions and consciousness. In other words, to create a new human being, we must create a new proper social concrete reality. Thus, an attempt to create a psychology that ignores the historical development (or historical experience), social development (or social experience), and cultural development (or cultural experience) of higher mental functions cannot become a genuine, comprehensive and real science. In Vygotsky's view, psychology's main task is to create'man as a social type' out of 'man as a biological type' (Vygotsky, 1927/1997, 6 p.58).

\section{Premises of historical dialectical materialism}

Psychology did not appear in Marxist literature until the creative studies of Lev Vygotsky, 1896-1934; Georges Politzer, 1903-1942, and Henri Wallon 1879-1962. Vygotsky's cultural historical research program is an area of rapidly expanding influence that has brought together scholars from a range of different disciplines such as psychology, linguistics, anthropology, education, philosophy and sociology. Vygotsky concluded that the human mind consists of innate reaction plus conditional reflexes plus historical experience plus social experience plus doubled experience" (van der Veer, 2007, p.45). Doubled experience means consciousness. There were a number of attempts to create a Marxist psychology during the 1920 s and 1930s. These were less successful because of misunderstandings of Marxism, and indeed of psychology. If Marxism drew on German Hegelian philosophy, British political economics and French political socialism, then psychology drew on German materialist physiology, British empiricist philosophy and French Cartesian dualism.

The present paper attempts to clarify three central theses outlined by Vygotsky: first, psychology is in need of its own Das Kapital; second, it must create appropriate categories and concepts which express, describe, and study its object; and third, it must discover its unit of analysis or psychological cell. Anyone who could figure out the answer to these theses would thereby find the key to psychology as a whole.

\section{The roots of Marxist psychology}

Hegel's paradigm in philosophy emerged from the impact of the French Revolution, whereas Marx's historical materialist dialectical philosophy emerged from the impact of a new era of proletarian revolts (The revolts of 1838, The revolution of 1848, First International of 1864, the Paris Commune 1871); and Vygotsky's Marxist psychology emerged from the impact of a new socially organized form of social relations of production (October 1917 revolution) as well as from the crisis of psychology itself - as diagnosed by Bühler, 1926, 1927; Driesch, 1925; Koffka, 1926; Kostyleff, 1911; Politzer, 1928, 1929/1969a, 1929/1969b The development of human mental life, consciousness, and personality should be understood as a continuous struggle and a resolution of 
contradictions. It is surprising that Marxist ideas were omitted in the process of appropriation of Vygotsky in the West (Elhammoumi, 2001a; 2001b; 2002a; 2002b; 2002c; 2006; 2009; 2010). In conclusion, this means that Marxist psychology should remain within the orbit of Marx's paradigm.

\section{Marxist psychology within Marx's paradigm}

Vygotsky (1927/1997, p.340). argued that"Marxist psychology does not yet exist. It must be understood as a historical goal, not as something already given." Lompscher (2002) pointed out that "As a whole, Vygotsky's works contain a serious and engaging treatment of Marx's writings, especially concerning the roots of a dialectical historical materialist approach to psychology".

The central task of "psychology is to reveal the struggle waged by Soviet psychologists for dialecticalmaterialist principles to prevail in the science, for an active participation in socialist construction" (Petrovsky, 1990, p.9).

Vygotsky claimed to be attempting to "restore" Marx's ideas on the question of psychology in the same way, and for the same purposes, as Lenin (1978) had restored the Marxist position on the state in State and Revolution. For Vygotsky, whether Marxism in its pre1848"philosophical"form or its post-1848"scientific"form, it is neither a science nor a philosophy; it is a theory of consciousness.

As Vygotsky said explicitly in his 1926 Historical Meaning of the Crisis in Psychology, Marxism adheres unconditionally to the political forms of classless society, which is the true nature of human nature. Three main propositions can be drawn from Marxist psychology. Firstly, there is the general law of cultural development, which means that human higher mental functions have their origin in the processes of social relations of production. Secondly, there is the law of semiotic mediation, which means that human higher mental functions can be understood only if we understand the mediating role of signs and tools. Thirdly, there is the genetic method, which means that human higher mental functions can be understood only in the processes of their development and growth. Psychology is the science of social production of the individual with special emphasis on higher mental functions, consciousness, activity, praxis, and inner life. In this vein, Politzer (1929/1969a, p.170) pointed out that"Psychology by no means holds the "secret" of human affairs, simply because this "secret" is not of a psychological order". In other words, humans' psychological nature represents the aggregate of internalized social relations that have become functions for the individual and in turn structures his/her higher mental functions (Vygotsky, 1981, p.164). Vygotsky incorporated Marx's concept of labor - activity and praxis - to his ontologicalepistemological approach to the study of human higher mental functions. Vygotsky argued that:

'Labor is that fundamental pivot around which the life of society is structured and erected. Man's social life and his study of nature are linked to activity of labor' (1928/1993, p.119), and 'It is labor which created man' (1925/1994a, p.183).

'Labor, society, and nature are the three fundamental channels which guide educational and formative work in school' (1928/1993, p.11), and he added that 'Even man's intellect could not have developed outside the conditions of specifically human activity, in particular, outside of labor' (1928/1993, p.236).

In my view, social relations of production represent the unit of analysis of psychology, just as the cell is the unit of analysis for biology, the atom is the unit of analysis for physics, and value is the unit of analysis for economics. Social relations of production as a unit of analysis will free psychology from being mainly limited to academic audiences to enable a psychology that is involved in the changing of human nature. This leads to assuming that the social individual has changing psychological nature and that, as society develops new social relations, new forms of higher mental functions and consciousness emerge. For Marx, any psychology that ignored the historical development of human labor activity and human consciousness could not become a genuine and real psychological science.

In his 1927 book, Historical Meaning of the Crisis in Psychology, Lev Vygotsky formulated the four basic assumptions which characterized Marxist psychology around 1920. These assumptions are: First, psychology is in need of its own concepts, in other words it needs its own Die Grundrisse (Marx, 1858/1973); second, psychology is in need of its own categories, which means that psychology needs its own philosophy and 
philosophical categories; third, psychology is in need of its own method, which means the application of dialectical historical materialism as an appropriate method for psychology; and fourth, psychology is in need of its own Das Kapital. The system of ideas developed by Vygotsky in the Historical Meaning of the Crisis in Psychology belongs to the conceptualization and category of grand psychological theory in the manner of Pavlov and James, Binet and Freud. In my view, Historical Meaning of the Crisis in Psychology potentially represents to psychology what Origin of Species is to biology, Wealth of Nations is to capitalism, and Das Kapital is to Marxism.

This crisis is with us to the present day, as illustrated by lan Parker (2007), who exposes how mainstream western psychology is a tool of capitalist system and a means of control and oppression. He goes on to assert that most psychologists are content to ignore not merely the cultural-historical context of their research investigations, but often even the more immediate social and political context.

\section{Psychology is in need of its own Die Grundrisse}

In this paper I argue that the Grundrisse represents an excessively'objectivist'version of Marxism ${ }^{3}$ that treats psychology as an autonomous, self-reproducing entity. Entity based on the principles of dialectical, historical materialism. Grundrisse could be seen as a kind of laboratory for scientific psychology's concepts that were developed and revised in the writings of Das Kapital. For example, Marx developed the concept of alienation in relation to commodity production as the foundation for human higher mental life.

Psychology is in need of its own concepts. Wittgenstein (1953, p.232e). stated, "... in psychology there are experimental methods and conceptual confusion. (as in other cases conceptual confusion and methods of proof.)".

\section{Psychology is in need of its own Das Kapital}

Vygotsky, Politzer and Wallon begin their developments of a Marxist psychology in a period dominated by Freudo-Marxism, Sechenov's and Bekhterev's reflexology, Pavlov's conditional reflexes, Kornilov's reactology, among others. A critical review of the struggle for the establishment of a Marxist psychology reminds us that an objective reading of The German Ideology, Die Grundrisse, and Das Kapital is imperative. Wallon's, Politzer's and Vygotsky's arguments against a hasty syntheses of Marxism and Pavlovism, Marxism and psychoanalysis, Marxism and behaviorism, Marxism and Darwinism, Marxism and empiricism are, therefore, accurate and compelling. Vygotsky (1927/1997, p.342) pointed out: "After all, our task is not at all to isolate our work from the general psychological work of the past, but to unite our work with all scientific achievement of psychology into one whole, and on a new basis". In my view, the topic of Marxist psychology needs continued discussion and much more elaboration.

\section{Marxist psychology: From concepts and categories to unit of analysis}

In order to understand Marx's psychological ideas, it is necessary to set aside previous psychological theoretical frameworks, and approach with a fresh mind such questions as: What is the task of psychology? How do human higher mental functions come to be? What shapes our cognition, consciousness, and personality?

To answer these questions, psychologists working within a Marxist theoretical framework need decades more time for the preparation of a Marxist psychology project. If you want to understand what is going on in social history, the best starting point is to look at the economic relations of production in that society and try to fit everything else into that. The social relation of production is the cornerstone that regulates concrete social life, human rule-governed behavior, consciousness, activity, higher mental functions and inner life. Social relations of production regulate our psychological mode of production, psychological forces of production, and psychological means of production. Production of all human cognitive tools such as thought

3 Some versions of Marxism are dead, but the Marxist tradition is still with us. As long as cruel injustices, poverty, inequality, and repression exist, Marxist tradition as developed in German Ideology, Die Grundrisse and Das kapital contain the elements to end and change them. 
production, consciousness, personality and constructs, shape our way of behaving and acting in socially organized practical activity.

The history of Marxist psychology has suffered greatly from psychologists' use of second-hand material and the consequent obliteration of the circumstances (dominance of positivist versions of Marxism) and the intellectual climate. A first hand study is always instructive, insightful and often, as in this case, full of surprises.

Anyone who wants to use or promote culturalhistorical psychology must be acquainted with Marx and Marxist traditions. Lompscher pointed out that: "In my opinion, it is an important - not the only, but one important - point of deeply understanding Vygotsky. Two remarks at the beginning:

1) When speaking about the development of cultural-historical psychology, it is not correct to limit our view only to Vygotsky, it is necessary to see him in close connection with his nearest co-workers Luria and Leontyev (the famous "troika", extended than to the "vosmyorka", when the team had 8 members and than was extended further) and their many co-workers and followers who used and elaborated his ideas further, concretized and specified them. In my short contribution, I'll speak about Vygotsky as the founder and outstanding representative of this whole scientific movement.

2) Here, I'll restrict myself to some aspects of the theory and methodology of cultural-historical psychology. It is not my point to ask, whether culturalhistorical psychology was or is or will be a consequent Marxist psychology or to which grade Vygotsky was a Marxist or where he made steps away from Marxism (as he was criticized by Kolbanovsky, the editor of Thinking and Speech after Vygotsky's death in 1934, and others). This is "a wide field", as said the German writer Theodor Fontane (but not in this connection). My point is which role played Marx in Vygotsky's thinking, how Vygotsky used Marx' philosophy and methodology and therefore: Is Vygotsky (2002) fully understandable without Marx? The latter is seen here as an outstanding representative of a materialist, dialectical and historical approach to nature, society, human being and consciousness".

\section{Conclusion}

In general, I think most work in "Marxist psychology" has stayed too close to both the form and content of bourgeois psychology and psychoanalysis. Furthermore, Western psychologists with an interest in Marxist approach to psychology have tended either to turn to psychoanalysis such as Freudo-Marxism, Frankfurt School of Critical Theory, and other positivist versions of Marxism or to concentrate on demonstrating the limitations of Western bourgeois psychology. I think they have tried to produce a Marxist version of psychology that has the same form as pre-Marxist psychology, fitting neatly into the same academic categories: cognition, motivation, perception, intelligence, attention, development, agency, subjectivity etc. The best theoretical tool for re-conceptualizing Marxist psychology is Marxism itself. In this vein, Vygotsky pointed out that,

Our science will become Marxist to the degree that it becomes truthful and scientific. And we will work precisely on making it truthful and to make it agree with Marx's theory Vygotsky (1927/1997, p.341).

It will have its geniuses and its ordinary investigators... our science will enter the new society on the threshold of which it begins to take shape. Our science could not and cannot develop in the old society. Vygotsky (1997, p.342).

Finally, this paper has shown that Marx's ideas have much to contribute to the discipline of scientific psychology or Marxist psychology, whose time has come.

\section{References}

Althusser, L. (1970a). Reading capital. London: New Left Books.

Althusser, L. (1970b). For Marx. London: New Left Books.

Arthur, C. (2002). The new dialectic and Marx's 'capital'. Leiden: Brill Academic Press.

Au, W. (2007). Vygotsky and Lenin on learning: the parallel structures of individual and social development. Science \& Society, 71 (3), 273-298.

Balibar, E. (1974). Cinq études du matérialisme historique. Paris: François Maspéro.

Bickley, R. (1977). Vygotsky's contribution to dialectical materialist psychology. Science \& Society, 41 (2), 191-207. 
Bidet, J. (2000). Que faire du 'capital'. Paris: Presses Univrsitaires de France.

Bühler, K. (1926). Die krise der psychologie. Kant Studien, 31 (51), 455-526.

Bühler, K. (1927). Die krise der psychologie. Frankfurt: Ungekürzte Ausg.

Chaiklin, S. (2001). The institutionalization of culturalhistorical psychology as a multinational practice. In S. Chaiklin (Ed.), The theory and practice of cultural-historical psychology (pp.15-34). Aarhus, Denmark: Aarhus University Press.

Clot, Y. (1977). Matérialisme historique et psychologie. In Y. Clot (Ed.), Piaget et le marxisme sur la théorie opératoire (pp.23-44). Paris: Centre d'Etudes et de Recherches Marxistes.

Driesch, H. (1925). The crisis in psychology. Princeton, NJ: Princeton University press.

Elhammoumi, M. (2001a). Lost-or merely domesticated? The boom in socio-historicocultural theory emphasizes some concepts, overlooks others. In S. Chaiklin (Ed.), The theory and practice of cultural-historical psychology (pp.200-217). Aarhus, Denmark: Aarhus University Press.

Elhammoumi, M. (2001b). Recepcion de Vigotsky en America Latina: Terreno fertil para una psicologia materialista. In M. Golder (Ed.), Vigotsky: psicologo radical (pp.51-66). Buenos Aires: Ateneo Vigotskiano de la Argentina.

Elhammoumi, M. (2002a). To create psychology's own capital. Journal for The Theory of Social Behavior, 32 (1), 89-104.

Elhammoumi, M. (2002b, June 18-22). Vygotsky via Marx: toward a marxist psychology. Paper presented at the Fifth Congress of the International Society for Cultural Research and Activity Theory (ISCRAT). Amsterdam, The Netherlands.

Elhammoumi, M. (2002C, June 18-22). Vygotsky's concept of culture: a Hegelian and Marxist analysis. Paper presented at the Fifth Congress of the International Society for Cultural Research and Activity Theory (ISCRAT). Amsterdam, The Netherlands.

Elhammoumi, M. (2006). Is there a Marxist psychology? In P. Sawchuk, N. Duarte \& M. Elhammoumi (Eds.), Critical perspectives on activity theory: explorations across education, work and the everyday life (pp.23-34). New York: Cambridge University Press.

Elhammoumi, M. (2009). Vygotsky's scientific psychology: terra incognita. Cultural-Historical Psychology: An International Scientific Journal, 3, 49-54.

Elhammoumi, M. (2010). Is 'back to Vygotsky' enough? The legacy of socio-historicocultural psychology. Psicologia em Estudo, 15 (4), 661-673.

Eskola, A. (1992). The legacy of Marxist influences in finnish psychology. Nordisk Psykologi, 44 (2), 97-103.

Holzkamp, K. (1992). On doing psychology critically. Theory \& Psychology, 2 (2), 193-204.

Koffka, K. (1926). Zur Krisis in der psychologie: bemerkungen zu dem buch gleichen namens von Hans Driesch. Die Naturwissenschaften, 14 (25), 581-586.
Kostyleff, N. (1911). La crise de la psychologie expérimentale:le présent et l'avenir. Paris: Alcan.

Lenin, V. I. (1978). State and revolution: marxist teaching about the theory of the state and the tasks of the proletariat in the revolution. Westport, Conn.: Greenwood Press.

Le Ny, J. F. (1970). Psychologie et matérialisme dialectique. Bruxelles: Éditions Le Pavillon.

Leontiev, A. N. (1978). Activity, consciousness, and personality. Englewood Cliffs, N.J.: Prentice-Hall.

Leontiev, A. N. (1981). Problems in the development of the mind. Moscow: Progress.

Lompscher, J. (2002 April 10). Is Vygotsky fully understandable without Marx. Private correspondence [Lenthy manuscript].

Luria, A. R. (1966). Vygotski et l'étude des fonctions psychiques supérieures. Recherches Internationales à la Lumière du Marxisme, 51, 93-103.

Malrieu, P. (1983). Vers une recherche marxiste en psychologie. La Pensée, 235, 19-38.

Mather, R. (2003). Hegemony and marxist psychology. Theory and Psychology, 13 (4), 469-487.

Marx, K. (1963). Karl Marx: early writings. New York: McGrawHill. (Originally published in 1844).

Marx, K. (1973). Grundrisse. New York: Penguin Books. (Originally published in 1858).

Marx, K. (1976). Capital (Vol. 1). London: Penguin Books.

Marx, K., \& Engels, F. (1963). The Greman ideology. New York: International Publishers.

Naville, P. (1948). Psychologie, marxismeet materialisme. Paris: Marcel Rivière.

Newman, F., \& Holzman, L. (1993). Lev Vygotsky: revolutionary scientist. London: Routledge.

Packer, M. (2008). Is Vygotsky relevant? Vygotsky's Marxist psychology. Mind, Culture and Activity, 15 (1), 8-31.

Parker, I. (2007). Revolution in psychology: alienation to emancipation. London: Pluto Press.

Petrovsky, A. (1990). Psychology in the Soviet Union: a historical outline. Moscow: Progress Publishers.

Politzer, G. (1928). Critique des fondements de la psychologie. Paris: Editions Sociales

Politzer, G. (1969a). Note sur la psychologie individuelle. In G. Politzer. Ecrits II: les fondements de la psychologye (pp.235-244). Paris: Editions Sociales. (Originally published in 1929).

Politzer, G. (1969b). Où va la psychologie concrète? In G. Politzer. Ecrits II: les fondements de la psychologie (pp.136-188). Paris: Editions Sociales. (Originally published in 1929).

Quiniou, Y. (1983). Marxisme et psychologie. La Pensée, 235, 125-129.

Reich, W. (1966). Dialectical materialism and psychoanalysis. Studies on the Left, 6 (4), 5-46. (Originally published in 1929). 
Reich, W. (1972). What is class-consciousness? In W. Reich (Ed.), Sex-Pol: essays 1920-1934 (pp.277-357). New York: Random House. (Originally published in 1934).

Roth, W. M., \& Lee, Y. J. (2007). Vygotsky's neglected legacy: cultural-historical activity theory. Review of Educational Research, 77 (2), 186-232.

Sartre, J. P. (1960). The problem of method. London: Methuen.

Sawchuk, P., Duarte, N., \& Elhammoumi, M. (Eds.). (2006). Critical perspectives on activity theory: explorations across education, work and the everyday life. New York: Cambridge University Press.

Sekine, T. (1997). An outline of the dialectic of capital (Vol.1,2). London: Macmillan Press.

Sève, L. (1966). Psychologie et marxisme. La Nouvelle Critique, $180,1-23$

Sève, L. (1975). Marxism and the theory of human personality. London: Lawrence \& Wishart.

Sève. L. (1978). Man in Marxist theory and the psychology of personality. Hassocks: Harvester Press.

Sève, L. (1989). Dialectique et psychologie chez Vygotski. Enfance, 42 (1/2), 11-16.

Sève, L. (2002). Quelles contradictions? A propos de Piaget, Vygotsky et Marx. In Y. Clot (Ed.), Avec Vygotsky (pp.245-264). Paris: La Dispute.

Sève, L. (2008). Heuristique: l'exemple majeur de l'oeuvre Vygotskienne. In L. Sève. Penser avec Marx aujourd'hui: "L'homme"? (Vol. 2, pp.309-371). Paris: La Dispute.

Shah-Shuja, M. (2008). Zones of proletarian development. London: Openmute.

Shames, C. (1984). Dialectics and the theory of individuality. Psychology \& Social Theory, 4, 51-65.

Spears, R., \& Parker, I. (Eds.). (1996). Psychology and society: radical theory and practice. London: Pluto Press.

Tobach, E. (1999). Evolution, genetics and psychology: the crisis in psychology, Vygotsky, Luria and Leontiev revisited. In S. Chaiklin, M. Hedegaard \& U. J. Jensen (Eds.), Activity theory and social practice (pp.136-160). Aarhus, Denmark: Aarhus University Press.
Uno, K. (1980). Principles of politicaleconomy. Sussex: Harvester Press.

van der Veer, R. (2007). Lev Vygotsky. New York: Continuum International Publishing Group.

Veresov, N. (1999). Undiscovered Vygotsky: etudes on the prehistory of cultural-historical psychology. New York: Peter Lang.

Vergnaud, G. (2000). Lev Vygotski: pédagogue et penseur de notre temps. Paris: Hachette Éducation.

Vygotsky, L. (1981). The genesis of higher mental functions. In J. Wertsch (Ed.), The concept of activity in Soviet psychology (pp.144-188). Armonk: M. E. Sharpe.

Vygotsky, L. S. (1987). The collected works of L. S. Vygotsky: problems of general psychology (Vol. 1). New York: Plenum Press. (Originally published in 1933).

Vygotsky, L. (1989). Concrete human psychology. Soviet Psychology, 27 (2), 53-77.

Vygotsky, L. (1993). The collected works of L. S. Vygotsky: the fundamentals of defectology: abnormal psychology and learning disabilities (Vol. 2). New York: Plenum Press. (Originally published in 1928).

Vygotsky, L. (1994a). La conscience comme problème de la psychologie du comportement. Société française, 50, 35-50.

Vygotsky, L. (1994b). The Vygotsky reader. Oxford: Basil Blackwell.

Vygotsky, L. S. (1997). The collected works of L. S. Vygotsky: problems of the theory and history of psychology (Vol. 3, pp.341-342). New York: Plenum Press. (Originally published in 1927).

Wallon, H. (1951). Psychologie et matérialisme dialectique. Enfance, 16 (1-2), 31-34.

Wittgenstein, L. (1953). Philosophical investigations. New York: MacMillan.

Recebido em: 8/8/2011

Aprovado em: 25/8/2011 
